\title{
New Strategies for Allergen T Cell Epitope Identification: Going beyond IgE
}

\author{
Véronique Schulten Bjoern Peters Alessandro Sette \\ La Jolla Institute for Allergy and Immunology, La Jolla, Calif., USA
}

\section{Key Words}

Subcutaneous specific immunotherapy - T cell epitopes . Th2 cells $\cdot$ Timothy pollen

\begin{abstract}
Background: Type I allergy and allergic asthma are common diseases in the developed world associated with IgE antibodies and Th2 cell reactivity. To date, the only causative treatment for allergic disease is specific immunotherapy (SIT). Method: Here, we review recent works from our laboratory focused on identifying human $T$ cell epitopes associated with allergic disease and their potential use as biomarkers or therapeutic targets for SIT. In previous studies, we have mapped T cell epitopes associated with the major 10 timothy grass $(\mathrm{Tg})$ allergens, defined on the basis of human IgE reactivity by ELISPOT. Results: Interestingly, in about $33 \%$ of allergic donors, no T cell epitopes from overlapping peptides spanning the entire sequences of these allergens were identified despite vigorous $\mathrm{T}$ cell responses to the $\mathrm{Tg}$ extract. Using a bioinformatic-proteomic approach, we identified a set of 93 novel Tg proteins, many of which were found to elicit IL-5 production in T cells from allergic donors despite lacking IgE reactivity. Next, we assessed T cell responses to the novel Tg proteins in donors who had been treated with subcutaneous SIT. A subset of these proteins showed a strong reduction of IL-5 responses in donors who had received subcutaneous SIT compared to allergic donors, which correlated with patients' self-reported improvement of allergic symptoms. Conclusion: A bioinformatic-proteomic approach has successfully identified additional Tg-
\end{abstract}

\section{KARGER}

E-Mail karger@karger.com

www.karger.com/iaa derived T cell targets independent of IgE reactivity. This method can be applied to other allergies potentially leading to the discovery of promising therapeutic targets for allergen-specific immunotherapy.

(c) 2014 S. Karger AG, Basel

\section{Introduction}

In this review, we present an overview of present and historical work in our laboratory to identify and characterize T cell-stimulatory epitopes from known and previously undescribed timothy grass $(\mathrm{Tg})$ proteins. Despite the importance of T cells in mediating type I allergy, there is still a significant lack of information on the epitopes they recognize. We combined several different methods with the intent to develop an approach for comprehensive $\mathrm{T}$ cell epitope mapping. As reviewed herein, this strategy is highly effective for mapping a highly diverse repertoire of $\mathrm{T}$ cell epitopes.

\section{Allergic Disease in Modern Society}

Allergic rhinoconjunctivitis is a common disorder in the developed world, posing a significant burden to the individuals who are directly affected, but also to society as a whole [1]. In a large scale study set out to measure the prevalence of allergic rhinitis among adults in Central Europe, it was reported that about $23 \%$ of the population suffered from clinically confirmable allergic rhinitis [2].
(C) 2014 S. Karger AG, Basel

$1018-2438 / 14 / 1652-0075 \$ 39.50 / 0$
Correspondence to: Dr. Véronique Schulten

La Jolla Institute for Allergy and Immunology

9420 Athena Circle

La Jolla, CA 92037 (USA)

E-Mail veronique@liai.org 
Similar data were obtained in studies conducted in children living in North America, estimating that approximately $13-17 \%$ of children in the United States suffer from allergic rhinitis $[3,4]$. The clinical presentation includes nasal, ocular and throat symptoms associated with fatigue and other mood and cognitive disturbances [5]. Physical impairments and decreased quality of life are often underestimated and can be severe in both adults and adolescents. Moreover, type I allergy is frequently associated with asthma, a disease characterized by episodic exacerbations of partially reversible airflow limitations, bronchial hyperreactivity and airway inflammation [6]. Accordingly, significant effort has been made over the last decades to gain a better understanding of the causes and immunological events involved in this disease.

One of the most frequent triggers of allergenic rhinitis and asthma is grass pollen; irrespective of the latitude, it is found almost all over the world [7]. This trigger is estimated to be responsible for allergic symptoms in up to $50 \%$ of patients with allergy [8-10]. The resulting clinical manifestations range from milder symptoms such as rhinoconjunctivitis to severe asthma attacks [2]. Due to this high impact and clinical relevance, grass pollen allergy is among those most heavily studied. Tg represents one of the most common sources of grass pollen allergens in the world. In previous studies, 10 different $\mathrm{Tg}$ allergens have been identified based on their ability to bind to human IgE [11]. Over the past few decades, most of these allergens have been produced in recombinant form $[12,13]$. IgE responses in $\mathrm{Tg}$-allergic patients have been characterized [14], and many B and T cell epitopes have been identified [15-29]. This thorough characterization of the Tgspecific $\mathrm{B}$ and $\mathrm{T}$ cell repertoire in different donor cohorts makes Tg one of the most-well-studied allergenic triggers to date in terms of immune response targets.

\section{Identification of T Cell Epitopes from Known and Novel Tg Antigens}

The importance of $\mathrm{T}$ cells in the regulation and maintenance of allergic disease has been well established in the last decades. However, antigens that are considered allergenic triggers are typically defined based on their ability to bind specific IgE antibodies $[11,30]$ and induce IgEmediated immediate hypersensitivity reactions [31], while the potential of the allergen to trigger $\mathrm{T}$ cell reactivity is in many cases not very well studied and is not taken into account when categorizing a protein as an allergen.
In a previous study, we performed a comprehensive screen to identify $\mathrm{T}$ cell epitopes from all $10 \mathrm{Phl} \mathrm{p}$ allergens known at the time [15]. Tg extract-stimulated peripheral blood mononuclear cells from allergic donors were cultured for 14 days with IL-2 and subsequently tested for $\mathrm{T}$ cell reactivity in response to a panel of overlapping peptides from all 10 allergens by means of IL-5 ELISPOT. During this screen, an interesting observation was made: While most of the donors responded to a variable selection of the peptides tested, in about a third of the donors no $\mathrm{T}$ cell response could be detected despite robust IL-5 production to Tg extract.

This observation led to the hypothesis that in addition to those allergens already identified by IgE reactivity, additional $\mathrm{Tg}$ proteins may be targeted by $\mathrm{T}$ cell responses. To test this hypothesis, we aimed to investigate $\mathrm{T}$ cell antigenicity of additional proteins on a broad scale. Since the Tg genome has not been sequenced, discovery of new $\mathrm{Tg}$ proteins required a sophisticated approach involving transcriptomic analysis of mRNA sequences obtained from Tg pollen coupled with a proteomic analysis to identify pollen proteins by mass spectrometry (MS) [32] (fig. 1). As a first step, Tg extract was run on a $2 \mathrm{D}$ gel, blotted onto nitrocellulose and probed with a serum pool from allergic patients to reveal immune reactivity of extract proteins. Although many of the extract proteins did bind IgE, a large fraction of proteins either only bound to IgG or were not recognized at all by antibodies despite being highly abundant in the Tg extract as revealed by the Coomassie stain. Several of these protein spots were cut out and subjected to MALDI-TOF MS analysis. Spectra obtained by MS were then compared to a cDNA library generated from mRNA sequences of Tg pollen, to reveal the transcripts that encoded the proteins.

This approach led to the identification of 93 novel $\mathrm{Tg}$ proteins [32]. As a next step, to test our hypothesis regarding the existence of additional $\mathrm{Tg} \mathrm{T}$ cell antigens, we assessed whether any of these novel $\mathrm{Tg}$ proteins could induce $\mathrm{T}$ cell reactivity in cells from allergic donors. An HLA class II binding prediction algorithm previously validated [33] was employed to generate a library of candidate proteins. This allowed us to efficiently test for $\mathrm{T}$ cell reactivity, and bypass the need to express and isolate all 93 proteins or synthesize and test overlapping peptides for all identified proteins.

Accordingly, binding capacities of peptides derived from the novel $\mathrm{Tg}$ proteins were predicted for a panel of the 25 most common HLA MHC class II DR, DP and DQ molecules (fig. 1). This returned a set of 822 peptides predicted to bind promiscuously to MHC class II molecules
Schulten/Peters/Sette 


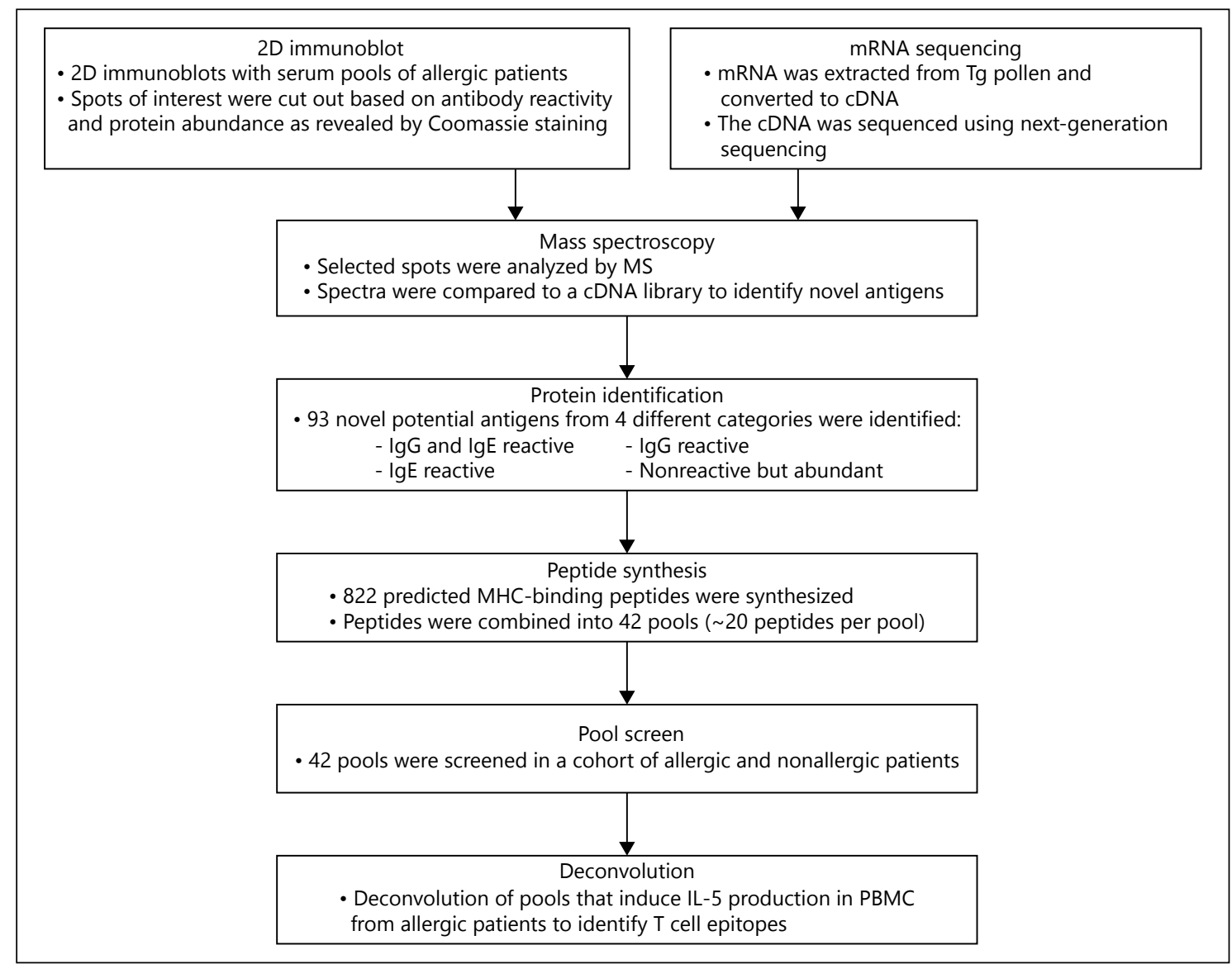

Fig. 1. A schematic presentation of the processes involved in the identification of novel Tg antigens and derived $\mathrm{T}$ cell epitopes. $\mathrm{PBMC}=$ Peripheral blood mononuclear cells.

( $\geq 12$ HLA variants predicted to be bound). These peptides were synthesized and tested as pools ( $\sim 20$ peptides per pool) in ELISPOT assays using Tg extract-expanded $\mathrm{T}$ cell cultures derived from 20 allergic donors (fig. 1). Twenty healthy donors were included as controls. Pools that elicited robust IL- 5 or IFN $\gamma$ responses were deconvoluted to identify the exact $\mathrm{T}$ cell epitope (fig. 1).

The data obtained from this screen clearly indicated that a significant fraction of the Th2 responses in allergic donors target $\mathrm{T}$ cell epitopes derived from these novel proteins. In fact, 13 out of 93 proteins elicited IL-5 responses in $20 \%$ or more of allergic donors tested [32]. In contrast, none of the antigens elicited IL- 5 responses in more than $10 \%$ of control donors and the total response magnitude was 4 -fold lower in controls compared to allergic donors. Table 1 shows a summary of these 13 antigens, their immunological reactivity and their identity as far as could be determined.

Discovery of Novel T Cell Antigens in Timothy Grass
Interestingly, 7 of the $13 \mathrm{~T}$ cell antigens that elicited IL-5 in allergic donors did not exhibit any IgE binding as determined by the $2 \mathrm{D}$ immunoblot. Although this observation is very interesting, $2 \mathrm{D}$ immunoblot analysis is a crude method and not sufficiently sensitive for reliable characterization of antibody reactivity. The lack of IgE reactivity observed for the 7 antigens of interest will have to be confirmed in individual patients by additional methods such as radioallergosorbent test or immune solid-phase allergy chip.

Further characterization of the $\mathrm{T}$ cell responses targeting novel $\mathrm{Tg}$ antigens was performed to exclude artifacts induced by in vitro priming in the culture. Memory and naïve $\mathrm{T}$ cell populations were sorted ex vivo based on the expression of the chemokine markers CD45RA and CCR7. The sorted subsets were expanded in vitro with Tg extract. ELISPOT assays with pools from the most dominant IL5 -inducing peptides from either novel (19 peptides ac- 
Table 1. Previously undescribed Tg antigens that elicit Th2 responses in $\geq 20 \%$ of patients tested

\begin{tabular}{|c|c|c|c|c|c|c|c|c|}
\hline & \multirow[t]{2}{*}{ Antigen } & \multicolumn{2}{|c|}{$\begin{array}{l}\text { Antibody } \\
\text { reactivity }\end{array}$} & \multicolumn{2}{|c|}{$\begin{array}{l}\text { T cell responses } \\
\text { (20 donors) }\end{array}$} & \multicolumn{3}{|c|}{ Biochemical characteristics } \\
\hline & & $\operatorname{IgE}$ & $\operatorname{IgG}$ & $\begin{array}{l}\% \\
\text { responders }\end{array}$ & $\begin{array}{l}\text { positive } \\
\text { peptides }^{2}\end{array}$ & $\begin{array}{l}\text { MW } \\
\mathrm{Da}\end{array}$ & rice homolog & biol. function \\
\hline M09 & 49 & - & - & 25 & $24 / 26$ & 61,860 & putative L-ascorbate oxidase & multicopper oxidase \\
\hline M34 & 54 & - & - & 20 & $8 / 12$ & 61,860 & putative L-ascorbate oxidase & multicopper oxidase \\
\hline M76 & 91 & - & - & 20 & $5 / 5$ & 19,987 & hypothetical protein & $\begin{array}{l}\text { cyclophilin-type peptidylprolyl } \\
\text { cis-trans isomerases }\end{array}$ \\
\hline M82 & 89 & - & - & 45 & $10 / 13$ & 91,646 & NA & NA \\
\hline M83 & 22 & - & - & 20 & $3 / 5$ & 29,529 & NA & NA \\
\hline MN26 & 53 & - & + & 30 & $4 / 5$ & 33,002 & $\begin{array}{l}\text { glycerophosphoryl diester } \\
\text { phosphodiesterase } \\
2 \text { precursor-like protein }\end{array}$ & $\begin{array}{l}\text { glycerophosphodiester } \\
\text { phosphodiesterase }\end{array}$ \\
\hline M28 & 52 & - & + & 30 & $26 / 29$ & 39,991 & NA & NA \\
\hline MN23 & 24 & + & - & 30 & $16 / 32$ & 43,095 & NA & NA \\
\hline M40 & 2 & + & + & 35 & $13 / 15$ & 61,976 & hypothetical protein & glucose-6-phosphate isomerase \\
\hline M81 & 62 & + & + & 25 & $8 / 9$ & 36,936 & hypothetical protein & secretory peroxidase \\
\hline M31 & 6 & + & + & 55 & $12 / 12$ & 51,423 & hypothetical protein & UDP-glucose pyrophosphorylase \\
\hline M65 & 7 & + & + & 25 & $4 / 5$ & 45,939 & hypothetical protein & isocitrate dehydrogenase (NADP+) \\
\hline M32 & 46 & + & + & 25 & $5 / 8$ & 10,115 & NA & NA \\
\hline
\end{tabular}

counting for $40 \%$ of the total IL- 5 response) or known ( 20 peptides accounting for $90 \%$ of the total IL-5 response) antigens were performed after 14-day expansion cultures. These assays revealed that $\mathrm{T}$ cell responses in the memory population were much greater compared to the naïve population. Finally, responses to both the novel and known peptide pool could also be detected directly ex vivo in sorted Th2 (CXCR3-CC4+) and Th1 (CXCR3+CC4-) cells.

These data confirmed our hypothesis that the reactivity gap observed between known allergens and whole $\mathrm{Tg}$ extract is explained by additional $\mathrm{T}$ cell antigens, some of which are not targeted by IgE or IgG. Thus, the universe of allergenic $\mathrm{T}$ cell antigens expands well beyond those proteins that are targeted by IgE responses. This combined unbiased transcriptomic, proteomic and immunomic approach (as outlined in fig. 1) is also applicable to other allergen sources, thus providing the potential to greatly broaden the repertoire of protein antigens targeted by $\mathrm{T}$ cells directly involved in type I allergy. Furthermore, our data demonstrate that unlinked $\mathrm{T}$ cell help is operational in Tg-specific immune responses, providing a novel insight into the immunological mechanisms associated with allergic reactions.

\section{Benefits and Limitations of Current Specific Immunotherapy Regimens}

The discovery of proteins that induce strong Th2 responses but are not targeted by IgE suggests the exciting possibility of new targets for safe and effective immunotherapy, which is to date the only causative treatment of allergic disease $[34,35]$. Allergen avoidance, albeit effective, is most often not feasible, especially so in the case of pollen allergies. Hence, effective treatment of allergic manifestations is required. A variety of drugs are available to manage day-to-day allergic symptoms. Pharmacobased treatments have, however, no direct effect on the immunological processes involved in sustaining IgE sensitization and allergy but rather they interfere with differ- 
ent immunological processes, such as mast cell degranulation, neutralization of certain mast cell mediators, suppression of $\mathrm{T}$ cell activation, general anti-inflammatory activity and/or reverse vasodilation and bronchoconstriction [36].

Because of their symptomatic nature, drugs effective in treating allergic disease rely on repeated administrations, and a more permanent treatment addressing the underlying cause of the disease is desired. In this context, specific immunotherapy (SIT) provides an effective alternative. SIT typically involves either subcutaneous or sublingual administration of allergen extract, and has been shown to provide long-term benefits that typically persist even after treatment is discontinued $[34,37]$.

SIT has been utilized for over a century [38] and it remains to be the only allergen-specific, disease-modifying treatment available to this day $[39,40]$. For grass pollen allergy, both subcutaneous and sublingual SIT have been shown to induce immunomodulatory effects that effectively relieve patients of their symptoms [41, 42]. Although the exact mechanisms of SIT remain a subject of discussion, several hallmarks of treatment have been identified, including the induction of blocking IgG4 antibodies, IL-10-producing T regulatory cells and a reduction in Th2 responses [43-46].

Although SIT is an established method to effectively treat allergic disease in many patients, it is also associated with certain limitations mostly due to incomplete efficacy and safety concerns. Injections or oral uptake of the whole, unfractionated allergen extracts currently used for SIT does bear the risk of induction of adverse IgE-mediated reactions. As a result, SIT for patients at high risk (i.e. asthmatic patients with $\mathrm{FEV}_{1}<70 \%$ ) is not recommended, even though they are arguably the ones in highest need of an effective treatment. Accordingly, new approaches for the development of a safer but equally or more effective immunotherapy are required.

\section{Strategies for the Development of Safer SIT}

Adverse side effects associated with SIT most commonly result from IgE-mediated immunological events. It has been demonstrated that successful SIT is accompanied with measurable modulation of allergen-specific $\mathrm{T}$ cell responses [21, 43, 45]. Therefore, allergenic proteins have been engineered to include chemical alterations in the critical residues for IgE binding, while at the same time retaining their $\mathrm{T}$ cell reactivity. These recombinant allergens are commonly referred to as hypoallergens. Hy-

Discovery of Novel T Cell Antigens in

Timothy Grass poallergenic variants have been made for several $\mathrm{Tg}$ allergens, including Phl p 1 [47] and Phl p 5 [24, 48, 49].

Another approach to decreasing the risk of adverse reactions during SIT administration is the production of 'allergoids', a term to describe allergens that have been modified using chemicals, such as formaldehyde or glutaraldehyde, for treatment [50-52]. Hypoallergenic allergoids do present benefits and can achieve effective immunomodulation. However, the standardization and characterization of allergoid extracts have proven problematic because the potency of allergoids and the amount of major allergens in these complexes cannot be measured after the chemical modification.

An alternative approach, which is focused on improving the safety of SIT by removing IgE binding sites in order to reduce IgE-mediated immediate type reactions, is the use of T cell epitope-based peptides [53-55]. Peptides 12-15 amino acids in size are in general too short to bind or crosslink inflammatory cell-bound IgE but still retain their ability to target $\mathrm{T}$ cells. Initial studies performed in cat-allergic patients showed modest clinical efficacy but were also associated with frequent adverse reactions [56]. More recent trials employing larger mixtures of shorter peptides achieved more significant reductions in early- and latephase allergic reactions following allergen challenge [57]. In those studies, immune modulation in the form of reduced Th1 and Th2 cell responses and enhanced IL-10 production was observed. Recently, Spertini et al. [58] employed an approach in which 3 selected contiguous overlapping peptides derived from Bet $\mathrm{v} 1$ that lack IgE reactivity were used to treat birch pollen-allergic patients. The initial trial, which included 20 patients $(15=$ active injections, $5=$ placebo), produced promising data with regard to the safety and efficacy of this treatment. Although peptide-based allergen-specific immunotherapy is a very promising new approach that may provide better safety for cases where adverse reactions to SIT may be a real limitation, further research is needed to demonstrate its efficacy at inducing long-term clinical tolerance for different allergies. In addition, peptide immunotherapy relies on the definition of $\mathrm{T}$ cell epitopes of the allergen of interest. Despite considerable efforts in the field of $\mathrm{T}$ cell epitope identification for different allergens, this may still be a limiting factor for certain allergen-specific peptide-based immunotherapy approaches, and further research is needed to bridge those gaps.

In addition to avoiding IgE-binding and specifically targeting $\mathrm{T}$ cells, the role of antigen-presenting cells and their potential use in guiding the allergen-specific response away from Th2 towards responses dominated by $\mathrm{Th} 1$ and $\mathrm{T}_{\text {reg }}$ phenotypes are also currently actively inves- 
tigated. Toll-like receptor ligands are used in combination with allergens to shift the Th1/Th2 balance [59-61]. Ongoing clinical phase II and III trials generated encouraging data and suggested potential clinical efficacy of different adjuvants [reviewed in ref. 62].

In conclusion, SIT regimens are established as effective treatment for patients suffering from several IgE-mediated hypersensitivities, including hymenoptera venom allergy [63], allergic rhinitis [64] and allergic bronchial asthma [65]. However, several limitations regarding safety, applicability and standardization remain. The ultimate goal still to be achieved is to develop a treatment with welldefined molecules or complexes associated with equal or higher clinical efficacy, while not being associated with adverse side effects. Some of the novel Tg antigens identified by us have immunological characteristics (lack of $\operatorname{IgE}$ reactivity but targeted by T cells) that make them potential candidates for a therapeutic approach.

\section{Novel Tg Antigens as Targets in SIT}

As described above, improvement in the safety and efficacy of current SIT is highly desirable. Data generated during the discovery and characterization of the novel $\mathrm{Tg}$ antigens showed that a large subset of the proteins identified lacks the ability to bind IgE while retaining the capacity to activate $\mathrm{T}$ cells from allergic donors. Indeed, these are potentially highly desirable characteristics for potential SIT candidate proteins.

To assess the potential of the novel Tg antigens as candidates for SIT applications, we sought to characterize the $\mathrm{T}$ cell response of donors who had received SIT against the novel Tg peptides and subsequently compare them to responses from the independent allergic cohort [66]. Mirroring our previous study, peptide pools were screened for T cell reactivity by ELISPOT using Tg extract stimulated in 14-day in vitro cultures. The most striking observation revealed by this screen was a pronounced decrease in IL-5 production for both known $\mathrm{Phl} \mathrm{p}$ allergens and novel Tg antigens [66]. No difference in IL-10 production was detected, which was somewhat unexpected in light of previous observations $[43,67]$. However, this may be related to the fact that IL-10 production is often associated with early stages of SIT [43] and is not always found to persist in the maintenance phase associated with SIT [68].

The reduction in IL-5 production observed for the novel antigens was more pronounced in some antigens than others [66]. Accordingly, we selected a subset of 20 peptides derived from 6 antigens to constitute a pool as- sociated with the most pronounced downmodulation of IL-5 responses in SIT-treated donors compared to allergic donors. This peptide pool was tested in a new cohort of 20 allergic and 20 SIT donors. The drastic decrease in IL-5 production previously observed in SIT donors was replicated, and concomitantly a highly significant increase in IFN $\gamma$ was detected. Again, no difference in IL-10 production between the two cohorts was observed [66].

Encouraged by these data, we assessed if the reduction in IL-5 could be correlated with treatment efficacy. During recruitment of SIT donors for these studies, patients provided a subjective evaluation stating whether or not they felt the treatment had helped to alleviate their allergic symptoms. SIT donors were segregated into two groups depending on whether they judged SIT a success or not. When the data pertaining to the IL-5 response modulation were subsequently analyzed, as a function of these accounts, it revealed that the decrease in IL-5 was in fact much more pronounced in donors who self-reported benefit from the treatments versus those that did not [66].

Overall, these data suggest that $\mathrm{T}$ cell responses to selected epitopes may serve as a biomarker to assess SIT efficacy. Subsequent studies will assess $\mathrm{T}$ cell reactivity in a longitudinal rather than cross-sectional cohort, and include detailed study of antibody reactivity on a donor-todonor basis and objective, clinical readouts to measure allergic symptom improvement following SIT. This will further evaluate if modulation of Th2 responses to selected epitopes follows or precedes clinical improvement, and for how long the $\mathrm{T}$ cell modulation is stable.

In summary, numerous novel strategies and approaches are being pursued to improve the safety and efficacy of SIT based on the complex pathogenesis of allergic diseases and the strong need for effective cures. In the work reviewed here, we successfully employed a bioinformatic-, proteomic- and immunomic-based approach to identify and efficiently characterize a set of novel Tg antigens, which may be used as potential biomarkers or even therapeutic targets for allergen-specific IT. In our opinion, this approach can be applied to other allergies and therefore lead to the discovery of a much broader spectrum of potential therapeutic targets.

\section{Acknowledgment}

This project has been funded in whole or in part with Federal funds from the National Institutes of Allergy and Infectious Diseases, National Institutes of Health, Department of Health and Human Services, under contract No. HHSN272200700048C and U19 grant No. U19 AI100275.
Schulten/Peters/Sette 


\section{References}

1 Bousquet J, Van Cauwenberge P, Khaltaev N: Allergic rhinitis and its impact on asthma. J Allergy Clin Immunol 2001;108:S147-S334.

-2 Bauchau V, Durham SR: Prevalence and rate of diagnosis of allergic rhinitis in Europe. Eur Respir J 2004;24:758-764.

-3 Ait-Khaled N, Pearce N, Anderson HR, Ellwood P, Montefort S, Shah J: Global map of the prevalence of symptoms of rhinoconjunctivitis in children: the International Study of Asthma and Allergies in Childhood (ISAAC) Phase Three. Allergy 2009;64:123-148.

4 Meltzer EO, Blaiss MS, Derebery MJ, Mahr TA, Gordon BR, Sheth KK, Simmons AL, Wingertzahn MA, Boyle JM: Burden of allergic rhinitis: results from the Pediatric Allergies in America survey. J Allergy Clin Immunol 2009; 124:S43-S70.

5 Spector SL: Overview of comorbid associations of allergic rhinitis. J Allergy Clin Immunol 1997;99:S773-S780.

6 Bochner BS, Undem BJ, Lichtenstein LM: Immunological aspects of allergic asthma. Annu Rev Immunol 1994;12:295-335.

7 Burney P, Malmberg E, Chinn S, Jarvis D, Luczynska C, Lai E: The distribution of total and specific serum IgE in the European Community Respiratory Health Survey. J Allergy Clin Immunol 1997;99:314-322.

8 Heinzerling L, Frew AJ, Bindslev-Jensen C, Bonini S, Bousquet J, Bresciani M, Carlsen $\mathrm{KH}$, van Cauwenberge P, Darsow U, Fokkens WJ, Haahtela T, van Hoecke H, Jessberger B, Kowalski ML, Kopp T, Lahoz CN, Lodrup Carlsen KC, Papadopoulos NG, Ring J, Schmid-Grendelmeier P, Vignola AM, Wohrl S, Zuberbier T: Standard skin prick testing and sensitization to inhalant allergens across Europe - a survey from the GALEN network. Allergy 2005;60:1287-1300.

-9 Suphioglu C, Singh MB, Taylor P, Bellomo R, Holmes P, Puy R, Knox RB: Mechanism of grass-pollen-induced asthma. Lancet 1992; 339:569-572.

10 Pollart SM, Reid MJ, Fling JA, Chapman MD, Platts-Mills TA: Epidemiology of emergency room asthma in Northern California: association with IgE antibody to ryegrass pollen. J Allergy Clin Immunol 1988;82:224-230.

-11 Andersson K, Lidholm J: Characteristics and immunobiology of grass pollen allergens. Int Arch Allergy Immunol 2003;130:87-107.

-12 Nandy A, Petersen A, Wald M, Suck R, Kahlert H, Weber B, Becker WM, Cromwell $\mathrm{O}$, Fiebig H: Primary structure, recombinant expression, and molecular characterization of $\mathrm{Phl} \mathrm{p} \mathrm{4,} \mathrm{a} \mathrm{major} \mathrm{allergen} \mathrm{of} \mathrm{timothy} \mathrm{grass}(P h-$ leum pratense). Biochem Biophys Res Commun 2005;337:563-570.

13 Vrtala S, Susani M, Sperr WR, Valent P, Laffer S, Dolecek C, Kraft D, Valenta R: Immunologic characterization of purified recombinant timothy grass pollen (Phleum pratense) allergens (Phl p 1, Phl p2, Phl p 5). J Allergy Clin Immunol 1996;97:781-787.
14 Niederberger V, Laffer S, Froschl R, Kraft D, Rumpold H, Kapiotis S, Valenta R, Spitzauer $S$ : IgE antibodies to recombinant pollen allergens (Phl p 1, Phl p 2, Phl p 5, and Bet v 2) account for a high percentage of grass pollenspecific IgE. J Allergy Clin Immunol 1998; 101:258-264.

15 Oseroff C, Sidney J, Kotturi MF, Kolla R, Alam R, Broide DH, Wasserman SI, Weiskopf D, McKinney DM, Chung JL, Petersen A, Grey H, Peters B, Sette A: Molecular determinants of $T$ cell epitope recognition to the common timothy grass allergen. J Immunol 2010; 185:943-955.

16 Wurtzen PA, Bufe A, Wissenbach M, Madsen HO, Ipsen H, Arnved J, Van Neerven RJ: Identification of isoform-specific T-cell epitopes in the major timothy grass pollen allergen, Phl p 5. Clin Exp Allergy 1999;29:16141625 .

-17 Schenk S, Breiteneder H, Susani M, Najafian N, Laffer S, Duchene M, Valenta R, Fischer G, Scheiner O, Kraft D, et al: T-cell epitopes of $\mathrm{Phl} \mathrm{p}$ 1, major pollen allergen of timothy grass (Phleum pratense): evidence for crossreacting and non-crossreacting T-cell epitopes within grass group I allergens. J Allergy Clin Immunol 1995;96:986-996.

18 Muller WD, Karamfilov T, Kahlert H, Stuwe HT, Fahlbusch B, Cromwell O, Fiebig H, Jager L: Mapping of T-cell epitopes of Phl p 5: evidence for crossreacting and non-crossreacting T-cell epitopes within Phl p 5 isoallergens. Clin Exp Allergy 1998;28:1538-1548.

19 Friedl-Hajek R, Breiteneder H, Bohle B, Fischer G, Ebner C, Scheiner O: Conserved sequence motifs of CDR3 loops of TCR specific for two major epitopes of the grass pollen allergen Phl p 1. Int Immunol 1998;10:17251732.

20 Westritschnig K, Focke M, Verdino P, Goessler W, Keller W, Twardosz A, Mari A, Horak F, Wiedermann U, Hartl A, Thalhamer J, Sperr WR, Valent P, Valenta R: Generation of an allergy vaccine by disruption of the threedimensional structure of the cross-reactive calcium-binding allergen, Phl p 7. J Immunol 2004; 172:5684-5692.

21 Ebner C, Siemann U, Bohle B, Willheim M, Wiedermann U, Schenk S, Klotz F, Ebner H, Kraft D, Scheiner O: Immunological changes during specific immunotherapy of grass pollen allergy: reduced lymphoproliferative responses to allergen and shift from Th2 to Th1 in T-cell clones specific for Phl p 1, a major grass pollen allergen. Clin Exp Allergy 1997; 27:1007-1015.

22 Bonvalet M, Wambre E, Moussu H, Horiot S, Kwok WW, Louise A, Ebo D, Hoarau C, Van Overtvelt L, Baron-Bodo V, Moingeon P: Comparison between major histocompatibility complex class II tetramer staining and surface expression of activation markers for the detection of allergen-specific CD4(+) T cells. Clin Exp Allergy 2011;41:821-829.
23 Ball T, Fuchs T, Sperr WR, Valent P, Vangelista L, Kraft D, Valenta R: B cell epitopes of the major timothy grass pollen allergen, $\mathrm{Phl} p$ 1 , revealed by gene fragmentation as candidates for immunotherapy. FASEB J 1999;13: 1277-1290.

24 Schramm G, Kahlert H, Suck R, Weber B, Stuwe HT, Muller WD, Bufe A, Becker WM, Schlaak MW, Jager L, Cromwell O, Fiebig H: 'Allergen engineering': variants of the timothy grass pollen allergen $\mathrm{Phl} p 5 \mathrm{~b}$ with reduced IgE-binding capacity but conserved $\mathrm{T}$ cell reactivity. J Immunol 1999;162:2406-2414.

-25 Petersen A, Schramm G, Schlaak M, Becker WM: Post-translational modifications influence IgE reactivity to the major allergen $\mathrm{Phl} p$ 1 of timothy grass pollen. Clin Exp Allergy 1998;28:315-321.

26 Flicker S, Steinberger P, Ball T, Krauth MT, Verdino P, Valent P, Almo S, Valenta R: Spatial clustering of the IgE epitopes on the major timothy grass pollen allergen $\mathrm{Phl} \mathrm{p} 1$ : importance for allergenic activity. J Allergy Clin Immunol 2006;117:1336-1343.

27 Focke M, Mahler V, Ball T, Sperr WR, Majlesi Y, Valent P, Kraft D, Valenta R: Nonanaphylactic synthetic peptides derived from $B$ cell epitopes of the major grass pollen allergen, Phl p 1, for allergy vaccination. FASEB J 2001;15:2042-2044.

28 Ball T, Vrtala S, Sperr WR, Valent P, Susani M, Kraft D, Valenta R: Isolation of an immunodominant IgE hapten from an epitope expression cDNA library. Dissection of the allergic effector reaction. J Biol Chem 1994;269: 28323-28328.

29 Padavattan S, Flicker S, Schirmer T, Madritsch C, Randow S, Reese G, Vieths S, Lupinek C, Ebner C, Valenta R, Markovic-Housley Z: High-affinity IgE recognition of a conformational epitope of the major respiratory allergen $\mathrm{Phl} \mathrm{p} 2$ as revealed by X-ray crystallography. J Immunol 2009;182:2141-2151.

30 Basketter DA, Kimber I: Assessing the potency of respiratory allergens: uncertainties and challenges. Regul Toxicol Pharmacol 2011;61: 365-372.

- 31 Gieras A, Focke-Tejkl M, Ball T, Verdino P, Hartl A, Thalhamer J, Valenta R: Molecular determinants of allergen-induced effector cell degranulation. J Allergy Clin Immunol 2007; 119:384-390.

-32 Schulten V, Greenbaum JA, Hauser M, McKinney DM, Sidney J, Kolla R, Lindestam Arlehamn CS, Oseroff C, Alam R, Broide DH, Ferreira-Briza F, Grey HM, Sette A, Peters B: Previously undescribed grass pollen antigens are the major inducers of $\mathrm{T}$ helper 2 cytokineproducing $\mathrm{T}$ cells in allergic individuals. Proc Natl Acad Sci USA 2013;110:3459-3464.

33 Wang P, Sidney J, Dow C, Mothe B, Sette A, Peters B: A systematic assessment of MHC class II peptide binding predictions and evaluation of a consensus approach. PLoS Comput Biol 2008;4:e1000048. 
-34 Durham SR, Walker SM, Varga EM, Jacobson MR, O'Brien F, Noble W, Till SJ, Hamid QA, Nouri-Aria KT: Long-term clinical efficacy of grass-pollen immunotherapy. N Engl J Med 1999;341:468-475.

-35 Wilson DR, Lima MT, Durham SR: Sublingual immunotherapy for allergic rhinitis: systematic review and meta-analysis. Allergy 2005;60:4-12.

36 Hansel TT, Barnes PJ: New Drugs for Asthma, Allergy and COPD. Basel, Karger, 2001.

- 37 Durham SR, Emminger W, Kapp A, de Monchy JG, Rak S, Scadding GK, Wurtzen PA, Andersen JS, Tholstrup B, Riis B, Dahl R: SQstandardized sublingual grass immunotherapy: confirmation of disease modification 2 years after 3 years of treatment in a randomized trial. J Allergy Clin Immunol 2012;129: 717.e5-725.e5.

38 Noon L: Prophylactic inoculation against hay fever. Lancet 1911;i:1572-1573.

-39 Larche M, Akdis CA, Valenta R: Immunological mechanisms of allergen-specific immunotherapy. Nat Rev Immunol 2006;6:761771.

40 Bousquet J, Lockey R, Malling HJ: Allergen immunotherapy: therapeutic vaccines for allergic diseases. A WHO position paper. J Allergy Clin Immunol 1998;102:558-562.

41 Rossi RE, Monasterolo G: Evaluation of recombinant and native timothy pollen $(\mathrm{rPhl} \mathrm{p}$ $1,2,5,6,7,11,12$ and $n P h l p 4$ )-specific IgG4 antibodies induced by subcutaneous immunotherapy with timothy pollen extract in allergic patients. Int Arch Allergy Immunol 2004; 135:44-53.

-42 Fanta C, Bohle B, Hirt W, Siemann U, Horak F, Kraft D, Ebner H, Ebner C: Systemic immunological changes induced by administration of grass pollen allergens via the oral mucosa during sublingual immunotherapy. Int Arch Allergy Immunol 1999;120:218-224.

-43 Bohle B, Kinaciyan T, Gerstmayr M, Radakovics A, Jahn-Schmid B, Ebner C: Sublingual immunotherapy induces IL-10-producing $\mathrm{T}$ regulatory cells, allergen-specific $\mathrm{T}$-cell tolerance, and immune deviation. J Allergy Clin Immunol 2007;120:707-713.

44 Francis JN, Till SJ, Durham SR: Induction of IL-10+CD4+CD25+ T cells by grass pollen immunotherapy. J Allergy Clin Immunol 2003;111:1255-1261.

45 Mobs C, Slotosch C, Loffler H, Jakob T, Hertl M, Pfutzner W: Birch pollen immunotherapy leads to differential induction of regulatory $\mathrm{T}$ cells and delayed helper $\mathrm{T}$ cell immune deviation. J Immunol 2010;184:2194-2203.

46 Akdis CA, Blaser K: Mechanisms of allergenspecific immunotherapy. Allergy 2000;55: 522-530.

-47 Levin M, Rydnert F, Kallstrom E, Tan LW, Wormald PJ, Lindstedt M, Greiff L, Ohlin M: $\mathrm{Phl} \mathrm{p}$ 1-specific human monoclonal IgE and design of a hypoallergenic group 1 grass pollen allergen fragment. J Immunol 2013;191: 551-560.
8 Wald M, Kahlert H, Reese G, Krontal N, Zafred D, Keller W, Cromwell O, Fiebig H, Nandy A: Hypoallergenic mutants of the timothy grass pollen allergen $\mathrm{Phl} p 5$ generated by proline mutations. Int Arch Allergy Immunol 2012;159:130-142.

49 Wald M, Kahlert H, Weber B, Jankovic M, Keller W, Cromwell O, Nandy A, Fiebig H: Generation of a low immunoglobulin E-binding mutant of the timothy grass pollen major allergen Phl p 5a. Clin Exp Allergy 2007;37: 441-450.

50 Marsh DG, Norman PS, Roebber M, Lichtenstein LM: Studies on allergoids from naturally occurring allergens. III. Preparation of ragweed pollen allergoids by aldehyde modification in two steps. J Allergy Clin Immunol 1981;68:449-459.

51 Negro JM, Wheeler AW, Hernandez J, Youlten LJ, Pascual A, Garcia-Selles FJ, Pagan JA, Lopez-Sanchez JD, Miralles JC, Sarrio F, Milan JM, Contreras LG, Vidal D: Comparison of the efficacy and safety of two preseasonal regimens of glutaraldehyde modified, tyrosine-adsorbed parietaria pollen extract over a period of three years in monosensitive patients. Allergol Immunopathol (Madr) 1999;27:153-164.

-52 Passalacqua G, Albano M, Fregonese L, Riccio A, Pronzato C, Mela GS, Canonica GW: Randomised controlled trial of local allergoid immunotherapy on allergic inflammation in mite-induced rhinoconjunctivitis. Lancet 1998;351:629-632.

53 von Garnier C, Astori M, Kettner A, Dufour N, Heusser C, Corradin G, Spertini F: Allergen-derived long peptide immunotherapy down-regulates specific IgE response and protects from anaphylaxis. Eur J Immunol 2000;30:1638-1645.

54 Campbell JD, Buckland KF, McMillan SJ, Kearley J, Oldfield WL, Stern LJ, Gronlund $\mathrm{H}$, van Hage M, Reynolds CJ, Boyton RJ, Cobbold SP, Kay AB, Altmann DM, Lloyd CM, Larche M: Peptide immunotherapy in allergic asthma generates IL-10-dependent immunological tolerance associated with linked epitope suppression. J Exp Med 2009;206:15351547.

55 Tarzi M, Klunker S, Texier C, Verhoef A, Stapel SO, Akdis CA, Maillere B, Kay AB, Larche $\mathrm{M}$ : Induction of interleukin-10 and suppressor of cytokine signalling-3 gene expression following peptide immunotherapy. Clin Exp Allergy 2006;36:465-474.

56 Norman PS, Ohman JL Jr, Long AA, Creticos PS, Gefter MA, Shaked Z, Wood RA, Eggleston PA, Hafner KB, Rao P, Lichtenstein LM, Jones NH, Nicodemus CF: Treatment of cat allergy with T-cell reactive peptides. Am J Respir Crit Care Med 1996;154:1623-1628.

57 Oldfield WL, Larche M, Kay AB: Effect of Tcell peptides derived from Fel d 1 on allergic reactions and cytokine production in patients sensitive to cats: a randomised controlled trial. Lancet 2002;360:47-53.
8 Spertini F, Perrin Y, Audran R, Pellaton C, Boudousquie C, Barbier N, Thierry AC, Charlon V, Reymond C: Safety and immunogenicity of immunotherapy with Bet $\mathrm{v}$ 1-derived contiguous overlapping peptides. J Allergy Clin Immunol 2014;134:239.e13-240.e13.

59 Simons FE, Shikishima Y, Van Nest G, Eiden JJ, HayGlass KT: Selective immune redirection in humans with ragweed allergy by injecting Amb a 1 linked to immunostimulatory DNA. J Allergy Clin Immunol 2004;113: 1144-1151.

60 Senti G, Johansen P, Haug S, Bull C, Gottschaller C, Muller P, Pfister T, Maurer P, Bachmann MF, Graf N, Kundig TM: Use of A-type CpG oligodeoxynucleotides as an adjuvant in allergen-specific immunotherapy in humans: a phase I/IIa clinical trial. Clin Exp Allergy 2009;39:562-570.

61 Mothes N, Heinzkill M, Drachenberg KJ, Sperr WR, Krauth MT, Majlesi Y, Semper H, Valent P, Niederberger V, Kraft D, Valenta R: Allergen-specific immunotherapy with a monophosphoryl lipid A-adjuvanted vaccine: reduced seasonally boosted immunoglobulin $\mathrm{E}$ production and inhibition of basophil histamine release by therapy-induced blocking antibodies. Clin Exp Allergy 2003;33:11981208.

62 Pfaar O, Cazan D, Klimek L, LarenasLinnemann D, Calderon MA: Adjuvants for immunotherapy. Curr Opin Allergy Clin Immunol 2012;12:648-657.

63 Ross RN, Nelson HS, Finegold I: Effectiveness of specific immunotherapy in the treatment of hymenoptera venom hypersensitivity: a meta-analysis. Clin Ther 2000;22:351-358.

64 Ross RN, Nelson HS, Finegold I: Effectiveness of specific immunotherapy in the treatment of allergic rhinitis: an analysis of randomized, prospective, single- or double-blind, placebocontrolled studies. Clin Ther 2000;22:342350 .

65 Abramson MJ, Puy RM, Weiner JM: Allergen immunotherapy for asthma. Cochrane Database Syst Rev 2003;4:CD001186.

66 Schulten V, Tripple V, Sidney J, Greenbaum J, Frazier A, Alam R, Broide D, Peters B, Sette A: Association between specific timothy grass antigens and changes in TH1- and TH2-cell responses following specific immunotherapy. J Allergy Clin Immunol 2014, Epub ahead of print.

67 Nouri-Aria KT, Wachholz PA, Francis JN, Jacobson MR, Walker SM, Wilcock LK, Staple SQ, Aalberse RC, Till SJ, Durham SR: Grass pollen immunotherapy induces mucosal and peripheral IL-10 responses and blocking IgG activity. J Immunol 2004;172:3252-3259.

68 Wambre E, DeLong JH, James EA, TorresChinn N, Pfutzner W, Mobs C, Durham SR, Till SJ, Robinson D, Kwok WW: Specific immunotherapy modifies allergen-specific CD4(+) T-cell responses in an epitope-dependent manner. J Allergy Clin Immunol 2014;133:872.e7-879.e7. 